\title{
Biomonitoring of Toxic Elements in Plants Collected Near Leather Tanning Industry
}

\author{
Alex R. H. De La Cruz, ${ }^{a}$ Lorreine D. S. C. Ferreira, ${ }^{a}$ Vinicius P. Andrade ${ }^{a}$ and \\ Adriana Gioda ${ }^{(*, a}$
}

\author{
${ }^{a}$ Departamento de Química, Pontifícia Universidade Católica do Rio de Janeiro, \\ Rua Marquês de São Vicente, 225, 22451-900 Gávea, Rio de Janeiro-RJ, Brazil
}

\begin{abstract}
The present work aimed the study of atmospheric deposition of toxic elements near to a tannery industry by collecting black material deposited on leaf surfaces of cinnamon trees (Cinnamomum zeylanicum). Elements such as $\mathrm{As}, \mathrm{Ba}, \mathrm{Cr}, \mathrm{Cu}, \mathrm{Fe}, \mathrm{Ni}, \mathrm{Pb}, \mathrm{Sb}, \mathrm{V}$, and $\mathrm{Zn}$ were analyzed by inductively coupled plasma mass spectrometry (ICP-MS). For comparison purpose, black particles deposited on the leaf surface of lemon trees (Citrus lemon) collected away from the tannery industry were also analyzed. Results showed that the amount of toxic elements found in the black particles collected near tannery area was significantly higher than the amount of those measured in the comparison site. Enrichment factors (EF) of As and Cr were markedly impacted by anthropogenic emissions, whereas the other elements were moderately/slightly enriched. Cluster analysis (CA) identified the leather industry as the anthropogenic source, while As possibly comes from the wide use of pesticides and herbicides in agricultural practices. The results indicated that emissions from the leather industry and agricultural activities are the main source of pollution in this area.
\end{abstract}

Keywords: leather industry, ICP-MS, toxic elements, atmospheric particles

\section{Introduction}

Leather industry, an age-old activity, covers the manufacture of diverse consumer products (e.g. footwear, clothes, and leather goods), industrial processes, and has significant economic influence. However, this industry is considered of great concern because to turn the skin into leather (leather tanning) requires several stages and involves the use of large amounts of fresh water and several chemicals such as lime, sodium carbonate, sodium bicarbonate, common salt, sodium sulfite, chrome sulfate, oils, resins, biocides, among other reagents. ${ }^{1,2}$ Increased levels of chromium in the environment result from the improper discharge of solids, wastewater, and gaseous emission from anthropogenic activities such as leather tanning, steel alloys and stainless steel manufacture, chrome plating, fabrication of paint pigments, wood preserving, textile, ceramic glazes, electroplating, and other activities. ${ }^{3,4}$

Atmospheric deposition of toxic elements in form of particulate matter (PM) can attain soils and plants by either dry or wet deposition. Plants are essential organisms (biomonitors) of the ecosystem because they may improve

\footnotetext{
*e-mail: agioda@puc-rio.br
}

the air quality by filtering, absorbing and accumulating significant quantities of toxic elements. ${ }^{5}$ Biomonitoring studies using tree leaves as passive sampler are particularly useful because they have the advantage of high spatial and temporal distribution, low-cost, high distribution density and trapping of atmospheric particles, mostly on the entire leaf surface. ${ }^{6}$ The accumulation and distributions of contaminants in plants depend on the plant species, bioavailability and level of contaminants in the soil and air, and environmental conditions, such as rainfall, wind speed and direction and other factors.?

In the last years, several plant species have been used as bioindicators of elemental deposition from the atmosphere. ${ }^{8-10}$ For instance, pine tree leaves have been used as biological indicators for assessing toxic metal pollution by $\mathrm{Cd}, \mathrm{Pb}, \mathrm{As}$, and $\mathrm{Hg}$ in an industrial ecosystem in Turkey. ${ }^{11}$ Leaves of five plants: Padus serotina, Acer campestre, A. negundo, Quercus robur and Celtis occidentalis were used as bioindicators to assess the amount and concentration of contaminants in deposited dust in and around the urban city of Debrecen, Hungary, ${ }^{10}$ while in Beijing, China, fourteen plant species have been used as bioindicators to evaluate the air pollution in the urban area. ${ }^{12}$

The determination of $\mathrm{Cr}$ in environmental samples is of great importance due to its toxicity. Chromium is 
a hard steel-grey toxic metal element and may occur naturally as chromite $\left(\mathrm{FeCr}_{2} \mathrm{O}_{4}\right)$ in the environment. This element is usually found in two oxidation states: trivalent chromium $\left(\mathrm{Cr}^{\mathrm{III}}\right)$ and hexavalent chromium $\left(\mathrm{Cr}^{\mathrm{VI}}\right)$. Other valence states (less stable or short-lived) can also occur in biological materials. The trivalent form is more abundant and much less toxic and less mobile than $\mathrm{Cr}^{\mathrm{VI}}$. It acts as an essential dietary nutrient to the maintenance of normal glucose tolerance for human and animals in low doses, while $\mathrm{Cr}^{\mathrm{VI}}$ compounds are considered 1,000 times more toxic than $\mathrm{Cr}^{\text {III }} .{ }^{13}$ Its toxicity is related to its high redox potential, mobility, and ability to penetrate biological membranes. Chromium(VI) is also known as carcinogenic and mutagenic agent and can cause several diseases. ${ }^{14}$

Nova Esperança do Sul, a small city in the south of Brazil, is named capital of the boot and has a big tannery, whose main articles are semi-finished and finished fullgrain leather and their use is divided between furniture and automotive industries. ${ }^{15,16}$ These goods are mainly sold to the foreign market. In general, leather industries eliminate leftover materials and leather shaving wastes through burning. As the industry is located in the center of the city, there are complaints from the population due to the constant atmospheric emissions. ${ }^{17}$ The particles generated during the burning spread throughout the city, leaving the houses dirty, causing bad smell and health problems, although there is no official record. For this reason, the objective of this study was to verify if the black particles deposited in the soil and on the surfaces of plants are from the natural origin or are related to tanning activities. The specific goals of this study were (i) to investigate the levels of toxic elements (As, $\mathrm{Cr}, \mathrm{Cu}, \mathrm{Fe}$, $\mathrm{Ni}, \mathrm{Pb}, \mathrm{Sb}, \mathrm{V}$, and $\mathrm{Zn}$ ) present in the deposited material on the surface of the leaves of Cinnamomum zeylanicum, (ii) to assess contamination levels, and (iii) to identify the possible sources of toxic elements in an industrialized region (Nova Esperança do Sul, RS, Brazil).

\section{Experimental}

Study area

This study was conducted in the city of Nova Esperança do Sul (S1, 29²4'24”' S, 5449'50”'W), state of Rio Grande do Sul (RS), Brazil (Figure 1). The city (S1) is located in the southernmost part of the country with 5,087 inhabitants, ${ }^{18}$ and covers an area of about $190,85 \mathrm{~km}^{2}$ of which $0.72 \%$ is related to the urban area, $27.15 \%$ is used for agricultural activities and $72 \%$ is field. The climate is subtropical and the average temperature varies between a maximum of $38^{\circ} \mathrm{C}$ and a minimum of $-3^{\circ} \mathrm{C}$, with $17.8^{\circ} \mathrm{C}$ as medium temperature..$^{15}$ The average annual precipitation is of
$1795 \mathrm{~mm}$ and the relative humidity varies from 30 to $95 \%$. The predominant wind direction is from the southwest (called "minuano") and north. ${ }^{15}$ In this region, two sites were chosen: S1A (center), located about $300 \mathrm{~m}$ far from the tannery, and S1B (Planalto), located about $5 \mathrm{~km}$ from the tannery.

As the presence of sooty mold, a fungus spread by insects, may cause deposits of black particles on leaves of various plants, an erroneous affirmation may be stated if only the study area was evaluated. In order to identify if black particles deposited on leaf surface in S1 are from natural or anthropogenic origin, an area located about $100 \mathrm{~km}$ from Rio de Janeiro (RJ) without pollution of industries or traffic influence, but with tree leaves containing black particles on the leaf surfaces, was considered. Lumiar (S2, 22 $22^{\circ} 0.12^{\prime}$ S , $42^{\circ} 12^{\prime} 0^{\prime}$ 'W), district of Nova Friburgo, Brazil (Figure 1), is a mountainous region in the Atlantic Forest covering an area of $7 \mathrm{~km}^{2}$ with 5,000 inhabitants. ${ }^{18}$ Climate is warm and temperate with average annual precipitation and temperature of $1437 \mathrm{~mm}$ and $19.5^{\circ} \mathrm{C}$, respectively.

\section{Sampling}

Sampling of cinnamon tree (Cinnamon zeylanicum) leaves was carried out in three periods: May 2016 (P1), September 2016 (P2) and October 2017 (P3) at Nova Esperança do Sul (S1). Cinnamon trees grow in tropical areas, have leaves of medium size and are elongated, slender, and oval to lanceolate in shape. About $300 \mathrm{~g}$ of both leaves without black particles on its surface (termed clean leaves (CL)) at S1A (CLS1A) and S1B (CLS1B) and leaves with particles at S1A were collected in the three periods (Figure 1a). Leaves containing black particles were not found at site S1B. Additional dry leaves (DL) were also collected at S1A (DLS1A). Soil samples (about $500 \mathrm{~g}$ ) were also collected at the surface and at $10 \mathrm{~cm}$ depth in places adjacent to the trees from which leaf samples were collected (SS1A and SS1B).

For comparison purpose, clean leaves (CLS2) and leaves of lemon tree (Citrus lemon) covered by black particles (PS2) (Figure 1b) were collected at Lumiar (S2) on February 2017. Sampling collection was at a height of 1.5-2 $\mathrm{m}$ above the ground, using latex gloves, stored in self-sealing plastic bags and subsequently transported to the laboratory.

\section{Sample preparation and chemical analysis}

In the laboratory, the material (black particles) deposited on leaf surface was carefully removed using a plastic knife 

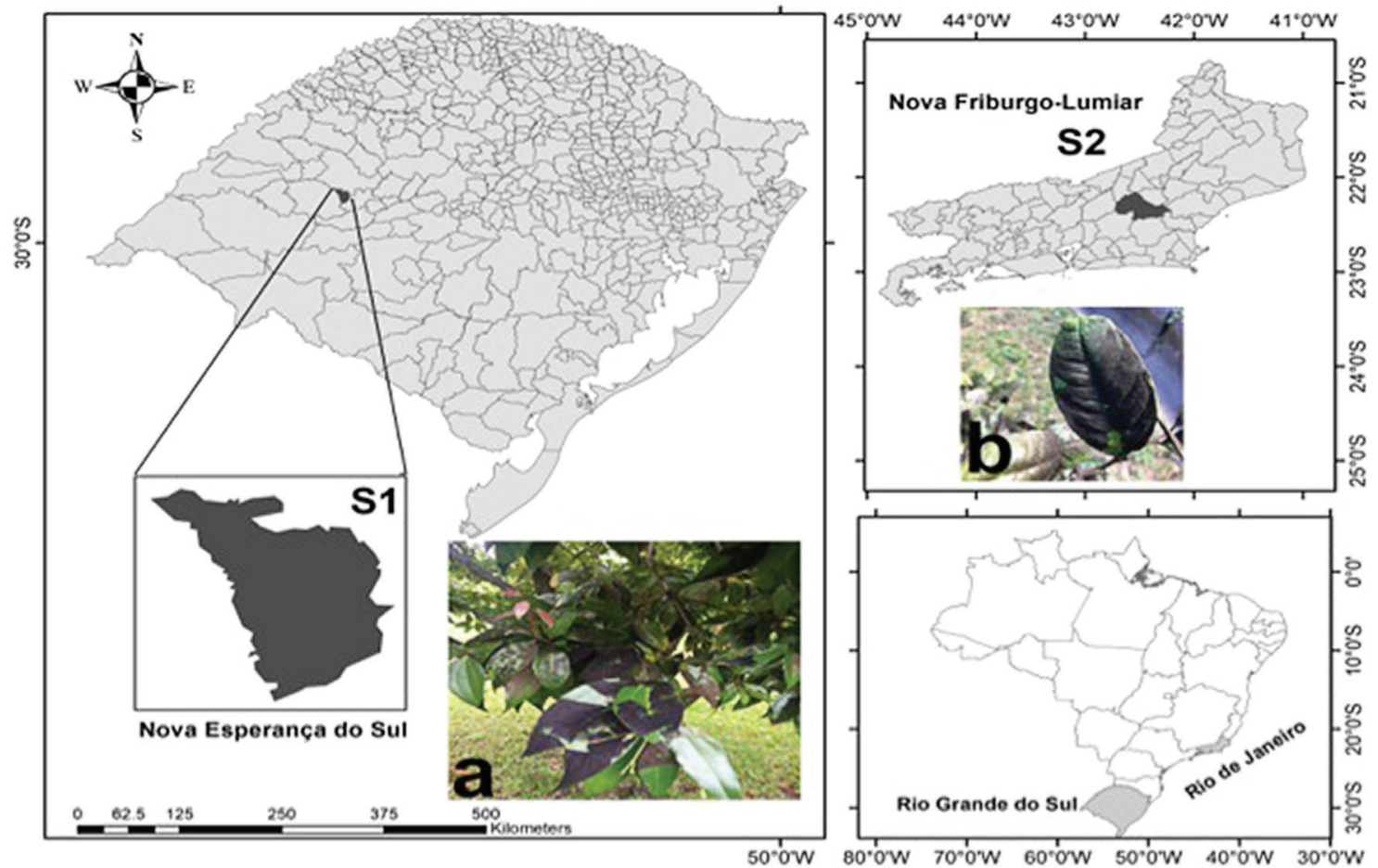

Figure 1. Location of the study area and samples collected in (S1) Nova Esperança do Sul, RS and (S2) Nova Friburgo-Lumiar, RJ. (a) Leaves of cinnamon tree covered by black particles at S1 and (b) leaves of citrus lemon tree covered by black particles at S2.

and stored in Falcon tubes $(50.0 \mathrm{~mL})$. From each site and period, approximately $5 \mathrm{~g}$ of black particles were removed from leaves surfaces to guarantee the homogeneity during analysis. The black particles, clean leaves, and soil samples were dried in an oven at $50{ }^{\circ} \mathrm{C}$ until completely dried. Dried samples were ground in agate ceramic mortar, homogenized, sieved (passed through a 100 mesh nylon sieve) and stored in Falcon tubes. The elements were extracted from $250 \pm 3 \mathrm{mg}$ samples using mixed-acid digestion $\mathrm{HNO}_{3}(3.0 \mathrm{~mL})+\mathrm{H}_{2} \mathrm{O}_{2}(0.5 \mathrm{~mL})$ and $\mathrm{HF}(0.1 \mathrm{~mL})$ method into a Teflon bottle (Savillex, Minnesota, USA) on a hotplate for $4 \mathrm{~h}$ at $250{ }^{\circ} \mathrm{C} \cdot{ }^{19} \mathrm{After}$ digestion, the samples were cooled, opened and evaporated at $175{ }^{\circ} \mathrm{C}$ to begin the drying. In order to remove remnant $\mathrm{HF}, 3.0 \mathrm{~mL}$ of $\mathrm{HNO}_{3}$ was added and evaporated two to three times ${ }^{20}$ and then transferred into a Falcon tube $(15.0 \mathrm{~mL})$ and diluted with deionized water. The concentration of $\mathrm{As}, \mathrm{Ba}, \mathrm{Cr}, \mathrm{Cu}, \mathrm{Fe}$, $\mathrm{Ni}, \mathrm{Pb}, \mathrm{Sb}, \mathrm{V}$, and $\mathrm{Zn}$ in the final solutions were measured by inductively coupled plasma mass spectrometry (ICP-MS) Elan DRC II mass spectrometer (PerkinElmer, USA). Prior analysis of ICP-MS, the instrumental parameters were adjusted to provide minimal oxide formation rates of $\mathrm{Ce}$ $(<3 \%)$ and double charged species ratio of $\mathrm{Ba}(<2 \%)$, respectively. Operating conditions for sample analysis by ICP-MS are presented in Table $1 .{ }^{103} \mathrm{Rh}$ was used as internal standard (IS) to correct and/or compensate non-spectral interferences and matrix effects. The elements were
Table 1. Instrumental conditions for the ICP-MS measurements

\begin{tabular}{lc}
\hline ICP-MS condition & Value \\
\hline RF power / W & 1150 \\
Frequency / MHz & 27.2 \\
Plasma gas flow rate / $\left(\mathrm{L} \mathrm{min}^{-1}\right)$ & 11.5 \\
Auxiliary gas flow rate / $\left(\mathrm{L} \mathrm{min}^{-1}\right)$ & 0.55 \\
Nebulizer gas flow rate / $\left(\mathrm{L} \mathrm{min}^{-1}\right)$ & 0.97 \\
Sample uptake rate / $\left(\mathrm{mL} \mathrm{min}{ }^{-1}\right)$ & 0.6 \\
Measurement mode & dual $(\mathrm{PC} / \mathrm{analog})$ \\
Acquisition time / s & 1 \\
Dwell time / ms & 200 \\
Replicate & 6 \\
\hline
\end{tabular}

The oxide ratio of $\mathrm{CeO}^{+} / \mathrm{Ce}^{+}$and double charged species ratio of $\mathrm{BaO}^{+} / \mathrm{Ba}^{+}$ were maintained below 0.03 and 0.02 , respectively. ICP-MS: inductively coupled plasma mass spectrometry; RF: radio frequency.

quantified through a six-point external calibration. Blank and triplicate samples were analyzed to provide quality control. The sample digestion and analysis procedure were checked using three certified reference material (CRMs): SRM 1648a (urban particulate matter), SRM 1515 (apple leaves), and SRM 8704 (Buffalo River sediment), which were published by National Institute of Standards and Technology (NIST, Gaithersburg, USA).

The limits of detection (LOD) and quantification (LOQ) were calculated as three and ten times the standard 
deviation of 10 blank measurements divided by the slope of the analytical curve. Table 2 shows the LOD, LOQ, and the extraction efficiencies of the CRMs used. As it can be seen, extraction efficiencies higher than $80 \%$ were obtained for most elements in both CRMs.

\section{Statistical analysis}

Differences between concentrations of toxic elements among clean leaves (CL), black particles collected at each period (P1, P2, and P3), and soil samples were analyzed by one-way analysis of variance (ANOVA), and subsequent post-hoc comparison was made using least significant difference (LSD) Tukey's test (value of $p<0.05$ was considered to be significant).

The enrichment factor (EF) using the concentration of each toxic element was calculated by equation 1 with the aim to evaluate the source contribution:

$\mathrm{EF}_{\mathrm{X}}=\frac{\left(\mathrm{C}_{\mathrm{x}} / \mathrm{C}_{\mathrm{n}}\right)_{\text {sample }}}{\left(\mathrm{C}_{\mathrm{X}} / \mathrm{C}_{\mathrm{n}}\right)_{\text {background }}}$

where $C_{X}$ and $C_{n}$ are the concentrations of the element $X$ and $\mathrm{n}$ in the sample and in the background. "Sample" refers to the concentrations of the elements present in the black particles removed from the leaves at Nova Esperança do Sul (S1) and Lumiar (S2), while "background" for S1 consists in the average soil composition value of both soils (superficial and deep) collected in the surroundings, ${ }^{21,22}$ while the crustal composition given by Taylor and McLennan ${ }^{23}$ was considered for $\mathrm{S} 2$. Fe was used as the reference. If $\mathrm{EF}<1$, the element is depleted in the environment and natural sources are predominant; if $\mathrm{EF}>1$, it means that the element is relatively enriched in the environment; while $\mathrm{EF}>5$ suggests that a large fraction of the element may be ascribed to anthropogenic sources..$^{24,25}$

Cluster analysis (CA) was used to identify and characterize the association of the group of elements as well as to have an idea of the probable source. Statistical analyses were performed using CRAN $\mathrm{R}^{26}$ free software through the following packages: ggplot $2,{ }^{27} \mathrm{dplyr},{ }^{28}$ and ClusterOfVar. ${ }^{29}$

\section{Results}

\section{Descriptive statistics}

Mean concentration \pm standard deviation (S.D.) and ANOVA results for $\mathrm{As}, \mathrm{Ba}, \mathrm{Cr}, \mathrm{Cu}, \mathrm{Fe}, \mathrm{Ni}, \mathrm{Pb}, \mathrm{Sb}, \mathrm{V}$, and $\mathrm{Zn}$ from each collection site measured in clean leaves of cinnamon at Nova Esperanca do Sul (S1) and of lemon at Lumiar (S2) collected in situ are shown in Table 3. Results show that there is a statistically significant difference among sampling sites $(p<0.05)$ for most of the elements measured, except for $\mathrm{Sb}$ (all sites) and $\mathrm{Ba}$ (S1A and $\mathrm{S} 1 \mathrm{~B}$ ). Dried leaves (DLS1A) collected show higher content of $\mathrm{Cr}, \mathrm{Cu}, \mathrm{Ni}$, and $\mathrm{V}$ than samples collected at the same site (CLS1A). However, it is very immature to attribute the death of the leaves to these elements. Differences $(p<0.05)$ found among elements measured from S2 and S1 may be ascribed to that the leaves were collected in different areas and from different tree species (cinnamon at $\mathrm{S} 1$ and lemon at S2). Plants, even being of the same species, accumulate different levels of pollutants if they grow in different

Table 2. Limits of detection and quantification by ICP-MS and concentration of certified reference materials of leaves (NIST SRM 151 - apple leaves), PM (NIST SRM 1648 - urban particulate matter) and sediment (NIST 8704 - Buffalo River sediment) used to evaluate the extraction efficiencies

\begin{tabular}{|c|c|c|c|c|c|c|c|c|c|c|c|}
\hline \multirow[b]{2}{*}{ Element } & \multirow[b]{2}{*}{$\begin{array}{l}\text { LOQ / } \\
\left(\mu \mathrm{g} \mathrm{g}^{-1}\right)\end{array}$} & \multirow[b]{2}{*}{$\begin{array}{l}\mathrm{LOD} / \\
\left(\mu \mathrm{g} \mathrm{g}^{-1}\right)\end{array}$} & \multicolumn{3}{|c|}{ SRM - apple leaves } & \multicolumn{3}{|c|}{ SRM - urban particulate matter } & \multicolumn{3}{|c|}{ SRM - Buffalo River sediment } \\
\hline & & & $\begin{array}{c}\text { Certified } \\
\text { value / } \\
\left(\mu \mathrm{g} \mathrm{g}^{-1}\right)\end{array}$ & $\begin{array}{l}\text { Found } \\
\text { value / } \\
\left(\mu \mathrm{g} \mathrm{g}^{-1}\right)\end{array}$ & $\begin{array}{c}\text { Extracted / } \\
\%\end{array}$ & $\begin{array}{c}\text { Certified } \\
\text { value / } \\
\left(\mu \mathrm{g} \mathrm{g}^{-1}\right)\end{array}$ & $\begin{array}{l}\text { Found } \\
\text { value / } \\
\left(\mu \mathrm{g} \mathrm{g}^{-1}\right)\end{array}$ & $\begin{array}{c}\text { Extracted / } \\
\%\end{array}$ & $\begin{array}{c}\text { Certified } \\
\text { value / } \\
\left(\mu \mathrm{g} \mathrm{g}^{-1}\right)\end{array}$ & $\begin{array}{l}\text { Found } \\
\text { value / } \\
\left(\mu \mathrm{g} \mathrm{g}^{-1}\right)\end{array}$ & $\begin{array}{c}\text { Extracted / } \\
\%\end{array}$ \\
\hline As & 0.004 & 0.013 & $0.038 \pm 0.007$ & $0.041 \pm 0.011$ & 108 & $115.5 \pm 3.9$ & $94.1 \pm 4.2$ & 81.5 & 17 & $16 \pm 2$ & 94 \\
\hline $\mathrm{Ba}$ & 0.11 & 0.36 & $49 \pm 2$ & $45.13 \pm 1.22$ & 77.9 & - & - & - & $413 \pm 13$ & $409 \pm 21$ & 99 \\
\hline $\mathrm{Cr}$ & 0.02 & 0.07 & 0.30 & $0.34 \pm 0.03$ & 113 & $402 \pm 13$ & $347 \pm 10$ & 86.3 & $121.9 \pm 3.8$ & $122.4 \pm 3.0$ & 100 \\
\hline $\mathrm{Cu}$ & 0.01 & 0.04 & $5.64 \pm 0.24$ & $4.94 \pm 0.51$ & 87.6 & $610 \pm 70$ & $616 \pm 21$ & 101 & $5.64 \pm 0.24$ & $5.04 \pm 0.34$ & 89 \\
\hline $\mathrm{Fe}$ & 4.16 & 13.73 & $83 \pm 5$ & $76 \pm 7$ & 91.0 & $3.92 \pm 0.21$ & $3.53 \pm 0.03$ & 90.0 & $3.97 \pm 0.10$ & $3.86 \pm 0.20$ & 97 \\
\hline $\mathrm{Ni}$ & 0.02 & 0.06 & $0.91 \pm 0.12$ & $1.02 \pm 0.05$ & 112 & $81.1 \pm 6.8$ & $80.3 \pm 5.2$ & 99.0 & $42.9 \pm 3.7$ & $41.5 \pm 2.12$ & 96 \\
\hline $\mathrm{Pb}$ & 0.09 & 0.30 & $0.47 \pm 0.02$ & $0.44 \pm 0.03$ & 93.3 & $6550 \pm 33$ & $6573 \pm 21$ & 94.2 & $150 \pm 17$ & $138 \pm 12$ & 92 \\
\hline $\mathrm{Sb}$ & 0.002 & 0.006 & 0.013 & $0.012 \pm 0.004$ & 90.9 & $45.4 \pm 1.4$ & $29.4 \pm 3.1$ & 65 & $3.07 \pm 0.32$ & $2.85 \pm 0.42$ & 93 \\
\hline V & 0.02 & 0.08 & $0.26 \pm 0.03$ & $0.30 \pm 0.04$ & 115 & $127 \pm 11$ & $138 \pm 8$ & 109 & $94.6 \pm 4.0$ & $91.2 \pm 3.2$ & 96 \\
\hline $\mathrm{Zn}$ & 0.15 & 0.49 & $12.50 \pm 0.30$ & $13.40 \pm 1.30$ & 107 & $4800 \pm 270$ & $4286 \pm 167$ & 89.2 & $408 \pm 15$ & $419 \pm 7$ & 103 \\
\hline
\end{tabular}

LOQ: limit of quantification; LOD: limit of detection; SRM: standard reference material; -: non reported. 
Table 3. Mean values \pm standard deviation (S.D.) and results of analysis of variance (ANOVA) of the elements measured in clean (CL) and dry leaves (DL) (without material deposited on the surface) collected at Nova Esperança do Sul (S1A and S1B) and Lumiar (S2)

\begin{tabular}{|c|c|c|c|c|c|}
\hline \multirow{3}{*}{ Element } & \multicolumn{4}{|c|}{ Mean \pm S.D. $/\left(\mu \mathrm{g} \mathrm{g}^{-1}\right)$} & \multirow{3}{*}{$\begin{array}{l}\text { ANOVA } \\
p \text {-value }\end{array}$} \\
\hline & \multicolumn{3}{|c|}{ S1 } & \multirow{2}{*}{$\begin{array}{c}\text { S2 } \\
\text { CLS2 }\end{array}$} & \\
\hline & CLS1A $300 \mathrm{~m}$ & DLS1A $300 \mathrm{~m}$ & CLS1B 5 km & & \\
\hline As & $0.37 \pm 0.06^{\mathrm{B}}$ & $0.44 \pm 0.05^{\mathrm{AB}}$ & $0.49 \pm 0.04^{\mathrm{A}}$ & $0.15 \pm 0.04^{\mathrm{C}}$ & a \\
\hline $\mathrm{Ba}$ & $65 \pm 5^{\mathrm{A}}$ & $63 \pm 3^{\mathrm{A}}$ & $69 \pm 3^{\mathrm{A}}$ & $27 \pm 3^{\mathrm{B}}$ & a \\
\hline $\mathrm{Cr}$ & $0.28 \pm 0.04^{C}$ & $3.82 \pm 0.88^{\mathrm{A}}$ & $0.78 \pm 0.08^{\mathrm{c}}$ & $2.58 \pm 0.20^{\mathrm{B}}$ & a \\
\hline $\mathrm{Cu}$ & $3.96 \pm 0.30^{\mathrm{C}}$ & $6.57 \pm 0.39^{\mathrm{B}}$ & $8.40 \pm 0.68^{\mathrm{A}}$ & $2.59 \pm 0.29^{\mathrm{D}}$ & a \\
\hline $\mathrm{Fe}$ & $113 \pm 8^{\mathrm{C}}$ & $135 \pm 19^{\mathrm{C}}$ & $180 \pm 35^{\mathrm{B}}$ & $573 \pm 18^{\mathrm{A}}$ & a \\
\hline $\mathrm{Ni}$ & $1.27 \pm 0.11^{\mathrm{C}}$ & $2.40 \pm 0.53^{\mathrm{B}}$ & $5.65 \pm 0.58^{\mathrm{A}}$ & $1.51 \pm 0.27^{\mathrm{C}}$ & a \\
\hline $\mathrm{Pb}$ & $0.12 \pm 0.03^{\mathrm{B}}$ & $0.15 \pm 0.02^{\mathrm{B}}$ & $0.26 \pm 0.03^{\mathrm{A}}$ & $0.29 \pm 0.04^{\mathrm{A}}$ & a \\
\hline $\mathrm{Sb}$ & $0.05 \pm 0.01$ & $0.03 \pm 0.02$ & $0.02 \pm 0.01$ & $0.03 \pm 0.01$ & n.d \\
\hline V & $0.12 \pm 0.03^{\mathrm{B}}$ & $0.51 \pm 0.14^{\mathrm{A}}$ & $0.42 \pm 0.07^{\mathrm{A}}$ & $0.42 \pm 0.04^{\mathrm{A}}$ & $\mathrm{b}$ \\
\hline $\mathrm{Zn}$ & $23 \pm 2^{\mathrm{A}}$ & $21 \pm 3^{\mathrm{A}}$ & $18 \pm 2^{\mathrm{B}}$ & $24 \pm 2^{\mathrm{A}}$ & b \\
\hline
\end{tabular}

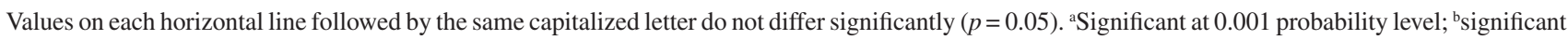
at 0.01 probability level; n.d: no difference.

environments. ${ }^{30}$ Similar to our results, Simon et al. ${ }^{31}$ found significant differences in concentrations of $\mathrm{Al}, \mathrm{Ba}, \mathrm{Cr}, \mathrm{Fe}$, $\mathrm{Mn}, \mathrm{Si}, \mathrm{Sr}$, and $\mathrm{Zn}$ among leaf tissues of three different trees and studied areas.

Table 4 shows the elemental concentrations of As, Ba, $\mathrm{Cr}, \mathrm{Cu}, \mathrm{Fe}, \mathrm{Ni}, \mathrm{Pb}, \mathrm{Sb}, \mathrm{V}$, and $\mathrm{Zn}$ analyzed and ANOVA results from black particles removed from the leaves collected at S1 (three periods, P1, P2, and P3) and S2 (PS2). All elements present higher concentration values at S1 than S2. Statistically significant differences were observed between the three periods at S1 and PS2 for most of the elements, suggesting that black particles do not have the same origin. A similar tendency was observed for all elements over the three periods.

The analyses of soil samples collected at $300 \mathrm{~m}$ and $5 \mathrm{~km}$ far from the tannery area (S1) are shown in Table 5. Results show minimal variation (not significant difference, $p>0.05$ ) between soils collected at $300 \mathrm{~m}$ for most elements, except Sb. In contrast, higher concentration values for all elements collected were observed at $300 \mathrm{~m}$ than $5 \mathrm{~km}$. These results may indicate the influence of anthropogenic sources.

Table 4. Mean values \pm standard deviation (S.D.) and results of the analysis of variance (ANOVA) of the elements measured in black particles collected at Nova Esperança do Sul (S1) during the three periods (P1, P2, and P3) and Lumiar (PS2)

\begin{tabular}{|c|c|c|c|c|c|}
\hline \multirow{3}{*}{ Element } & \multicolumn{4}{|c|}{ Mean \pm S.D. $/\left(\mu \mathrm{g} \mathrm{g}^{-1}\right)$} & \multirow{3}{*}{$\begin{array}{l}\text { ANOVA } \\
p \text {-value }\end{array}$} \\
\hline & \multicolumn{3}{|c|}{ S1 } & \multirow{2}{*}{$\begin{array}{c}\text { S2 } \\
\text { PS2 }\end{array}$} & \\
\hline & P1 & $\mathrm{P} 2$ & P3 & & \\
\hline As & $3.75 \pm 0.20^{\mathrm{AB}}$ & $4.12 \pm 0.38^{\mathrm{A}}$ & $3.13 \pm 0.62^{\mathrm{B}}$ & $0.34 \pm 0.05^{\mathrm{C}}$ & a \\
\hline $\mathrm{Ba}$ & $87 \pm 3^{\mathrm{AB}}$ & $91 \pm 3^{\mathrm{A}}$ & $83 \pm 6^{\mathrm{B}}$ & $61 \pm 2^{\mathrm{C}}$ & a \\
\hline $\mathrm{Cr}$ & $69 \pm 3^{\mathrm{A}}$ & $44 \pm 2^{\mathrm{B}}$ & $52 \pm 12^{\mathrm{B}}$ & $11 \pm 2^{\mathrm{C}}$ & a \\
\hline $\mathrm{Cu}$ & $18 \pm 2^{\mathrm{B}}$ & $25 \pm 3^{\mathrm{A}}$ & $26 \pm 2^{\mathrm{A}}$ & $4.14 \pm 0.46^{\mathrm{C}}$ & a \\
\hline $\mathrm{Fe}$ & $7484 \pm 189^{\mathrm{A}}$ & $7083 \pm 259^{A}$ & $7107 \pm 825^{\mathrm{A}}$ & $4745 \pm 123^{\mathrm{B}}$ & a \\
\hline $\mathrm{Ni}$ & $4.01 \pm 0.19^{\mathrm{A}}$ & $5.21 \pm 0.19^{\mathrm{B}}$ & $5.31 \pm 1.11^{\mathrm{B}}$ & $3.05 \pm 0.32^{\mathrm{B}}$ & a \\
\hline $\mathrm{Pb}$ & $5.10 \pm 0.41^{\mathrm{AB}}$ & $7.40 \pm 0.40^{\mathrm{A}}$ & $7.17 \pm 2.43^{\mathrm{A}}$ & $2.97 \pm 0.30^{\mathrm{B}}$ & b \\
\hline $\mathrm{Sb}$ & $0.37 \pm 0.04^{\mathrm{A}}$ & $0.54 \pm 0.05^{\mathrm{B}}$ & $0.29 \pm 0.02^{\mathrm{C}}$ & $0.05 \pm 0.02^{\mathrm{D}}$ & a \\
\hline V & $24 \pm 3^{\text {B }}$ & $32 \pm 3^{\mathrm{A}}$ & $25 \pm 2^{\mathrm{B}}$ & $6.2 \pm 0.3^{\mathrm{C}}$ & a \\
\hline $\mathrm{Zn}$ & $76 \pm 2^{\mathrm{B}}$ & $84 \pm 5^{\mathrm{A}}$ & $80 \pm 2^{\mathrm{AB}}$ & $30 \pm 4^{\mathrm{C}}$ & a \\
\hline
\end{tabular}

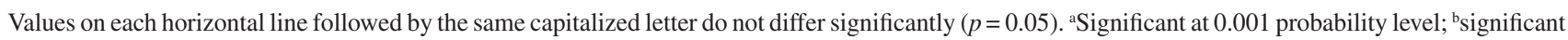
at 0.01 probability level. 
Table 5. Mean values \pm standard deviation (S.D.) and results of the analysis of variance (ANOVA) of the trace elements measured in soil samples collected at $300 \mathrm{~m}$ and $5 \mathrm{~km}$ of distance from the tannery area (all samples collected in October 2017)

\begin{tabular}{|c|c|c|c|c|}
\hline \multirow{3}{*}{ Element } & \multicolumn{3}{|c|}{ Mean \pm S.D. $/\left(\mu \mathrm{g} \mathrm{g}^{-1}\right)$} & \multirow{3}{*}{$\begin{array}{l}\text { ANOVA } \\
p \text {-value }\end{array}$} \\
\hline & Deep soil & Superficial soil & Deep soil & \\
\hline & $300 \mathrm{~m}$ & $300 \mathrm{~m}$ & $5 \mathrm{~km}$ & \\
\hline As & $5.79 \pm 1.20^{\mathrm{A}}$ & $5.92 \pm 1.19^{\mathrm{A}}$ & $1.54 \pm 0.34^{\mathrm{B}}$ & b \\
\hline $\mathrm{Ba}$ & $421 \pm 22^{\mathrm{A}}$ & $358 \pm 86^{\mathrm{A}}$ & $47.6 \pm 1.4^{\mathrm{B}}$ & a \\
\hline $\mathrm{Cr}$ & $47.78 \pm 2.24^{\mathrm{B}}$ & $60.93 \pm 3.82^{\mathrm{A}}$ & $5.43 \pm 0.14^{\mathrm{C}}$ & a \\
\hline $\mathrm{Cu}$ & $83.01 \pm 2.15^{\mathrm{A}}$ & $70.81 \pm 6.13^{\mathrm{B}}$ & $5.35 \pm 0.18^{\mathrm{c}}$ & a \\
\hline $\mathrm{Fe}$ & $54496 \pm 1427^{\mathrm{A}}$ & $54940 \pm 1486^{\mathrm{A}}$ & $4582 \pm 249^{\mathrm{B}}$ & a \\
\hline $\mathrm{Ni}$ & $13.68 \pm 1.50^{\mathrm{A}}$ & $9.93 \pm 0.83^{\mathrm{B}}$ & $2.10 \pm 0.03^{\mathrm{C}}$ & a \\
\hline $\mathrm{Pb}$ & $35.87 \pm 2.77^{\mathrm{A}}$ & $34.03 \pm 1.48^{\mathrm{A}}$ & $4.93 \pm 0.67^{\mathrm{B}}$ & a \\
\hline $\mathrm{Sb}$ & $1.24 \pm 0.79^{\mathrm{A}}$ & $0.45 \pm 0.07^{\mathrm{AB}}$ & $0.09 \pm 0.02^{\mathrm{B}}$ & n.d \\
\hline $\mathrm{V}$ & $167 \pm 27^{\mathrm{A}}$ & $183 \pm 29^{A}$ & $18.97 \pm 1.11^{\mathrm{B}}$ & a \\
\hline $\mathrm{Zn}$ & $197 \pm 5^{\mathrm{A}}$ & $209 \pm 9^{\mathrm{B}}$ & $14.73 \pm 2.14^{\mathrm{C}}$ & a \\
\hline
\end{tabular}

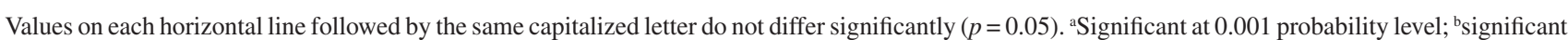
at 0.01 probability level; n.d: no difference.

\section{Enrichment factor (EF)}

The EF of each element was calculated according to equation 1 only for black particles collected at site S1A (three periods independently, P1, P2, and P3) and S2 and are shown in Figure 2. EF $>5$ suggests anthropogenic influence, as it is seen here for $\mathrm{Cr}$ (all periods) and As (P1 and P2) in site $\mathrm{SA} 1$, while $\mathrm{Ni}, \mathrm{Pb}, \mathrm{Ba}, \mathrm{Zn}, \mathrm{Sb}, \mathrm{V}$, and $\mathrm{Cu}$ present $1<\mathrm{EF}<4$, indicating a slight enrichment of these elements in the environment. In contrast, $\mathrm{EF} \leq 1$ were observed for $\mathrm{As}, \mathrm{Pb}, \mathrm{Ba}, \mathrm{Zn}, \mathrm{Sb}, \mathrm{V}$, and $\mathrm{Cu}$ at site $\mathrm{S} 2$ suggesting depletion of these elements in this area (except $\mathrm{Cr}$ and $\mathrm{Ni}$ ). This is not surprising because S2 is a rural area. In general, EF values were in the order: $\mathrm{Cr}>\mathrm{As}>\mathrm{Zn}>\mathrm{Ni}>\mathrm{Cu}>\mathrm{Sb}>$ $\mathrm{Ba}>\mathrm{V}>\mathrm{Pb}$, with $\mathrm{Cr}$ exhibiting always the highest levels during the three periods at S1A.

\section{Cluster analysis (CA)}

CA was applied to the concentration data of soils (superficial and deep) and black particles removed from leaves (three periods) collected at site S1A (black particles collected at S2 were not considered). The resulting dendrogram (Figure 3) revealed two main groups: $\mathrm{Cr}$ constitutes the group 1, cluster 1, while Ni, V, Zn, Fe, Ba, $\mathrm{Cu}$, and $\mathrm{Pb}$ (subgroup 2A) and $\mathrm{As}$ and $\mathrm{Sb}$ (subgroup 2B) constitute the group 2 . These results suggest that group 1 has an anthropogenic origin, while group 2 may have a mixture of both natural and anthropogenic sources.

\section{Discussion}

Concentration levels of Cr obtained near tannery area (300 m) for both soils and black particles were always higher than samples collected at $5 \mathrm{~km}$ and in the Lumiar site (S2). In terms of $\mathrm{EF}, \mathrm{Cr}(\mathrm{EF}>5)$ and $\mathrm{As}(\mathrm{EF}>5$, two first periods) were clearly enriched in the sampling periods in the center of Nova Esperança do Sul (S1A) and are likely associated with anthropogenic sources. In the literature, ${ }^{2,32-34}$ several researchers related high concentrations levels of $\mathrm{Cr}$ and other toxic metals found in groundwater, effluents, and soils due to poor waste management of leather industries. In the study area, chromium-tanned leather has been used for many decades in the manufacture of a large variety of leather-based products by several companies installed here; therefore, the enrichment of this element may be attributed to the tannery industry.

Arsenic is a metalloid that belongs to group 15 of the periodic table and occurs naturally in the environment. ${ }^{35}$ However, this element is related to cancer risk. ${ }^{36,37}$ Arsenic is used in the manufacture of several products such as glass, ceramics, electronics, cosmetics, in pesticides and herbicides formulations ${ }^{38}$ and biocides that usually are used to wastewater treatment. ${ }^{39}$ The land in the study area is used to produce a variety of products, such as corn, soy, tobacco, cassava, sugar cane and rice, and agrochemicals are usually employed by farmers. As there are no other industries in this area, we may affirm that most of found 

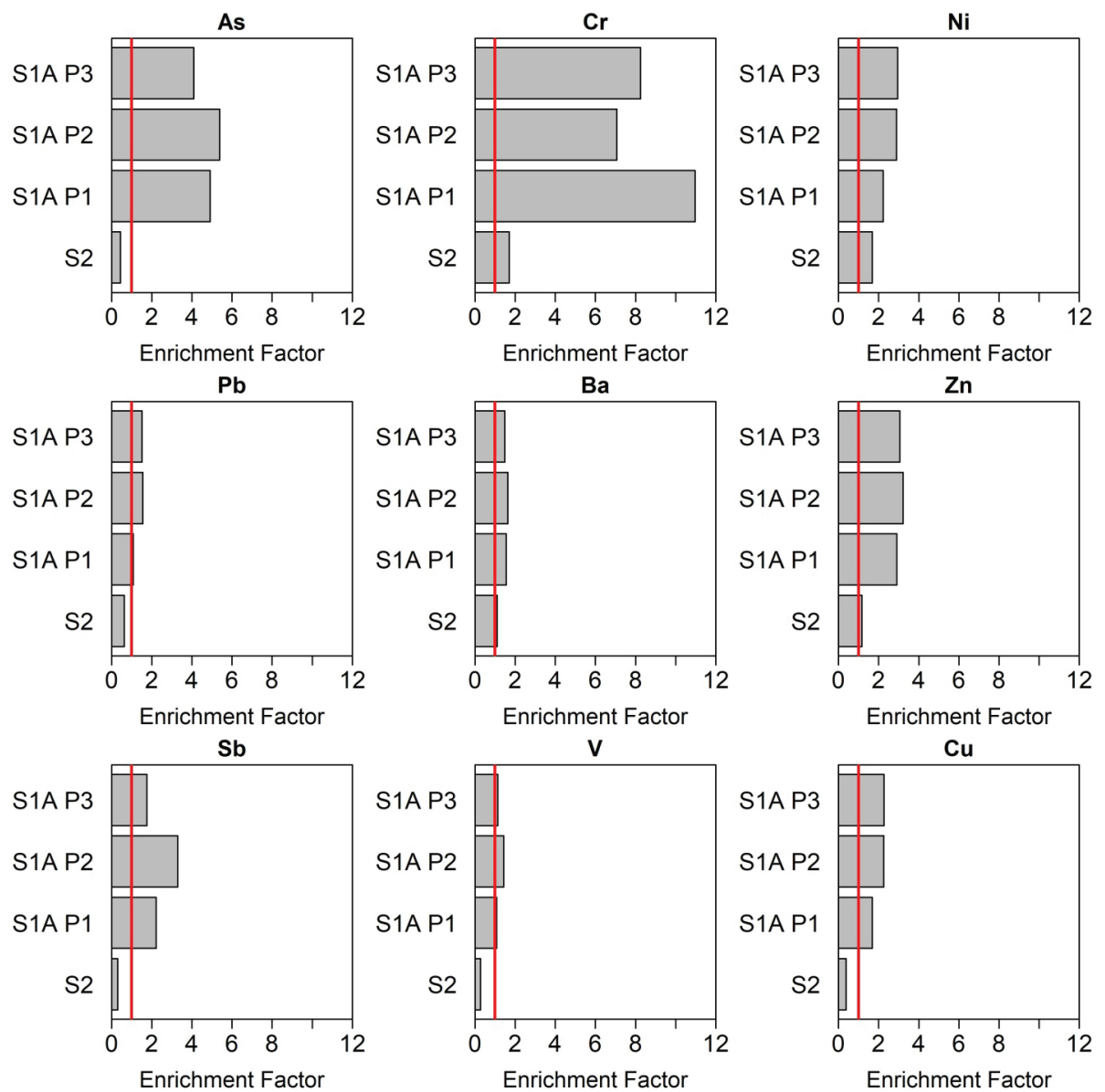

Figure 2. Comparison among EFs of the elements measured in black particles removed from leaves in Nova Esperança do Sul, RS (S1) (three periods: $\mathrm{P} 1, \mathrm{P} 2$, and P3) and Lumiar, RJ (S2). Fe is used as the reference element (red vertical line).

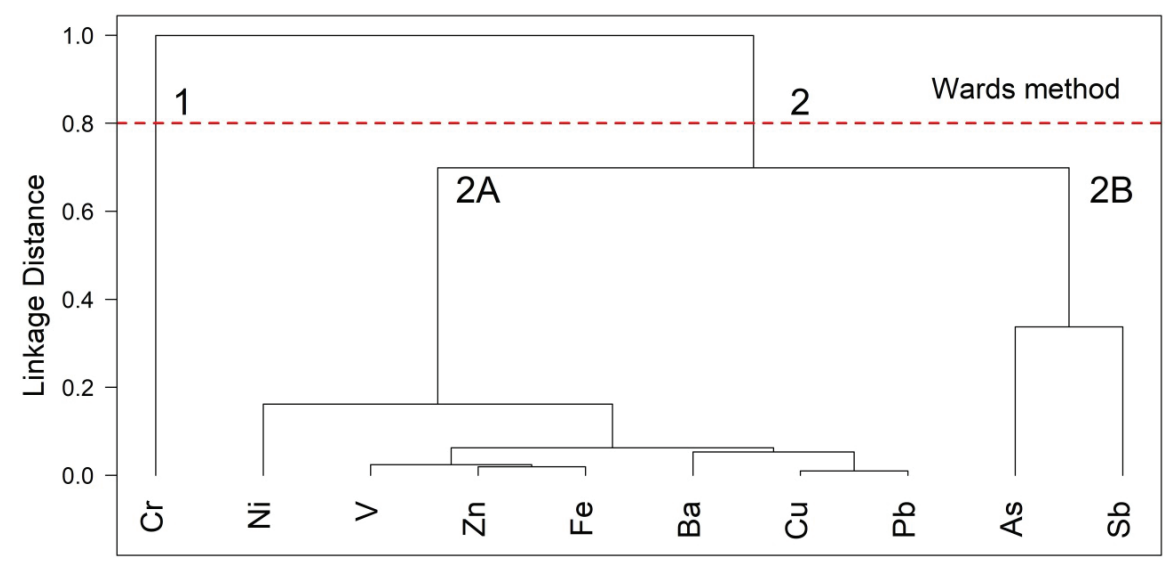

Figure 3. Dendrogram representing the grouping of elements based on analysis of black particles removed from leaves of the three sampling periods and soil samples collected at Nova Esperança do Sul, RS (S1A).

As are related to agricultural activities. In the literature, for instance, Zhou et al. ${ }^{38}$ determined As concentrations in arable soils and found an increasing accumulation trend over past decades, which is related to the long-term application of phosphate fertilizers in agricultural practice, while Bolan et al..$^{40}$ related this element to the production of rice grain and complementary medicines.
For the other elements $(\mathrm{Ni}, \mathrm{Pb}, \mathrm{Ba}, \mathrm{Zn}, \mathrm{Sb}, \mathrm{V}$, and $\mathrm{Cu})$ low enrichment was observed in this area. These elements usually are related to vehicular sources, ${ }^{41-44}$ and its low enrichment may be explained because this region is a rural area with reduced vehicular fleet.

The group 1 of CA shows clearly $\mathrm{Cr}$ as a separate variable, which is consistent with the fact that chromium is 
a key element in the tanning process to obtain leather. From subgroup 2B, it can be noted the presence of $\mathrm{Sb}$, which is a metalloid occurring naturally in the environment as trace elements. ${ }^{35}$ However, in the last decades, Sb was associated with traffic because several parts of the vehicle contain $\mathrm{Sb}$ alloys and other $\mathrm{Sb}$ compounds. ${ }^{45-47}$ As can be seen in the subgroup 2B from CA, arsenic is a little separated of the other elements, which may indicate that it is released from anthropogenic sources, but not necessarily from the same source as $\mathrm{Ni}, \mathrm{Cu}$, and $\mathrm{Zn}$. Arsenic also occurs naturally and it is noted for its relation with Sb. Both elements were related to anthropogenic activities that can produce adverse effects on humans and the environment. ${ }^{48}$

\section{Conclusions}

This study evaluated the content of toxic elements in a region surrounded by a tannery area, located at Nova Esperança do Sul, RS, Brazil. The results of the analysis of black particles collected near leather industry show a higher concentration of all elements analyzed, especially $\mathrm{Cr}$ in the three sampling periods compared to a rural area (Lumiar, RJ, Brazil). This result confirmed that the presence of black particles mostly is related to the leather industry than the presence of sooty mold spread by insects. In the same way, soil samples (both deep soil and surface soil) collected around tannery area showed higher concentration for all elements than deep soil collected at $5 \mathrm{~km}$ of distance. Enrichment factor higher than 5 were obtained for $\mathrm{Cr}$ (three periods) and As (two periods) suggesting the anthropogenic influence of both elements. Cluster analysis isolated $\mathrm{Cr}$ in the first group demonstrating clearly the influence of this element in the study area, whereas As was related to the use of agrochemicals (pesticides or herbicides) by farmers. On the other hand, $\mathrm{EF}>4$ for $\mathrm{Ni}, \mathrm{Pb}, \mathrm{Ba}, \mathrm{Zn}, \mathrm{Sb}$, and $\mathrm{Cu}$ were found, which is in agreement because the study area has rural characteristics.

\section{Acknowledgments}

The authors are grateful to CAPES, FAPERJ, and CNPq for financial support. A. G. thanks CNPq for the Bolsa de Produtividade and to FAPERJ for the Auxilio Cientista do Nosso Estado.

\section{References}

1. Mwinyihija, M.; Ecotoxicological Diagnosis in the Tanning Industry; Springer Science: Aberdeen, 2010.

2. Mondal, N. C.; Saxena, V. K.; Singh, V. S.; Environ. Geol. 2005, 48, 149.
3. Langárd, S.; Costa, M. In Handbook on the Toxicology of Metals, vol. 3, $3^{\text {rd }}$ ed.; Nordberg, G. F.; Fowler, B. A.; Nordberg, M.; Friberg, L. T., eds.; Academic Press: New York, 2007, ch. 24.

4. Monteiro, M. I. C.; Fraga, I. C. S.; Yallouz, A. V.; de Oliveira, N. M. M.; Ribeiro, S. H.; Talanta 2002, 58, 629.

5. Liang, J.; Fang, H. L.; Zhang, T. L.; Wang, X. X.; Liu, Y. D.; Urban For. Urban Greening 2017, 27, 390.

6. Tarricone, K.; Wagner, G.; Klein, R.; Ecol. Indic. 2015, 57, 341.

7. Filipović-Trajković, R.; Ilić, Z. S.; Šunić, L.; Andjelković, S.; J. Food Agric. Environ. 2012, 10, 959.

8. Deljanin, I. V.; Tomašević, M. N.; Urošević, M. P. A.; Antanasijević, D. Z.; Perić-Grujić, A.; Ristić, M.; Ecol. Indic. 2014, 45, 640 .

9. Bhattacharya, T.; Chakraborty, S.; Tuteja, D.; Patel, M.; Open J. Met. 2013, 3, 42.

10. Simon, E.; Baranyai, E.; Braun, M.; Cserháti, C.; Fábián, I.; Tóthmérész, B.; Sci. Total Environ. 2014, 490, 514.

11. Matin, G.; Kargar, N.; Buyukisik, H. B.; Ecol. Eng. 2016, 90 , 331.

12. Shi, J.; Zhang, G.; An, H.; Yin, W.; Xia, X.; Atmos. Pollut. Res. 2017, 8, 836 .

13. Kimbrough, D. E.; Cohen, Y.; Winer, A. M.; Creelman, L.; Mabuni, C.; Crit. Rev. Environ. Sci. Technol. 1999, 29, 1.

14. World Health Organization (WHO); WHO Air Quality Guidelines for Particulate Matter, Ozone, Nitrogen Dioxide and Sulfur Dioxide; WHO Press: Geneva, 2006. Available at http://apps.who.int/iris/bitstream/10665/69477/1/WHO_SDE_ PHE_OEH_06.02_eng.pdf, accessed in September 2018.

15. Paraginski, A. L.; Rev. Adm. Innov. 2014, 11, 55.

16. Giannetti, B. F.; Bonilla, S. H.; Almeida, C. M. V. B.; J. Cleaner Prod. 2004, 12, 361.

17. Joseph, K.; Nithya, N.; J. Cleaner Prod. 2009, 17, 676.

18. ftp://ftp.ibge.gov.br/Estimativas_de_Populacao/ Estimativas_2016/estimativa_dou_2016_20160913.pdf, accessed in August 2018.

19. Bing, H.; Wu, Y.; Zhou, J.; Sun, H.; Chemosphere 2016, 165, 388.

20. Ardini, F.; Soggia, F.; Rugi, F.; Udisti, R.; Grotti, M.; J. Anal. At. Spectrom. 2010, 25, 1588.

21. Liu, E.; Yan, T.; Birch, G.; Zhu, Y.; Sci. Total Environ. 2014, 476-477, 522.

22. Kara, M.; Dumanoglu, Y.; Altiok, H.; Elbir, T.; Odabasi, M.; Bayram, A.; Atmos. Res. 2014, 149, 204.

23. Taylor, S. R.; McLennan, S. M.; The Continental Crust: Its Composition and Evolution: An Examination of the Geochemical Record Preserved in Sedimentary Rocks; Blackwell Scientific Publications: Oxford, Melbourne, 1985.

24. Enamorado-Báez, S. M.; Gómez-Guzmán, J. M.; Chamizo, E.; Abril, J. M.; Atmos. Res. 2015, 155, 118.

25. Wu, Y. S.; Fang, G. C.; Lee, W. J.; Lee, J. F.; Chang, C. C.; Lee, C. Z.; J. Hazard. Mater. 2007, 143, 511. 
26. R Core Team; R: A Language and Environment for Statistical Computing; R Foundation for Statistical Computing, Vienna, Austria, 2015.

27. Wickham, H.; Chang, W.; Henry, L.; ggplot2: Elegant Graphics for Data Analysis, R Package Version 3.3.3; Springer-Verlag: New York, 2009. Available at https://cran.r-project.org/web/ packages/ggplot2/ggplot2.pdf, accessed in September 2018.

28. Wickham, H.; François, R.; Henry, L.; Müller, K.; dplyr: A Grammar of Data Manipulation, R Package Version 0.7.4.; 2017. Available at https://CRAN.R-project.org/package=dplyr, accessed in September 2018.

29. Chavent, M.; Kuentz, V.; Liquet, B.; Saracco, J.; ClustOfVar: Clustering of variables, R Package Version 0.8; 2013. Available at https://CRAN.R-project.org/package=ClustOfVar, accessed in September 2018.

30. Annan, K.; Dickson, R.; Nooni, I.; Amponsah, I.; Pharmacogn. Res. 2013, 5, 103.

31. Simon, E.; Harangi, S.; Baranyai, E.; Fábián, I.; Tóthmérész, B.; Urban For. Urban Greening 2016, 20, 12.

32. Srinivasa Gowd, S.; Ramakrishna Reddy, M.; Govil, P. K.; J. Hazard. Mater. 2010, 174, 113.

33. Febriana, S. A.; Jungbauer, F.; Soebono, H.; Coenraads, P. J.; Int. Arch. Occup. Environ. Health 2012, 85, 517.

34. Júnior, H. M.; da Silva, J.; Arenzon, A.; Portela, C. S.; Ferreira, I. C. F. S.; Henriques, J. A. P.; Chemosphere 2007, 67, 1211.

35. Wilson, S. C.; Lockwood, P. V.; Ashley, P. M.; Tighe, M.; Environ. Pollut. 2010, 158, 1169.
36. Morais, S.; Garcia e Costa, F.; Pereira, M. L. In Environmental Health - Emerging Issues and Practice, vol. 10; Oosthuizen, J., ed.; IntechOpen: Rijeka, 2012, p. 227-246.

37. Gamboa-Loira, B.; Cebrián, M. E.; Franco-Marina, F.; LópezCarrillo, L.; Environ. Res. 2017, 156, 551.

38. Zhou, Y.; Niu, L.; Liu, K.; Yin, S.; Liu, W.; Sci. Total Environ. 2018, 616-617, 156.

39. Bollmann, U. E.; Tang, C.; Eriksson, E.; Jönsson, K.; Vollertsen, J.; Bester, K.; Water Res. 2014, 60, 64.

40. Bolan, S.; Kunhikrishnan, A.; Chowdhury, S.; Seshadri, B.; Naidu, R.; Ok, Y. S.; Chemosphere 2017, 182, 433.

41. Kertész, Z.; Szoboszlai, Z.; Angyal, A.; Dobos, E.; BorbélyKiss, I.; Nucl. Instrum. Methods Phys. Res., Sect. B 2010, 268, 1924.

42. Akiyama, K.; Talanta 2006, 70, 178.

43. Matti Maricq, M.; J. Aerosol Sci. 2007, 38, 1079.

44. Amato, F.; Pandolfi, M.; Viana, M.; Querol, X.; Alastuey, A.; Moreno, T.; Atmos. Environ. 2009, 43, 1650.

45. Fujiwara, F.; Rebagliati, R. J.; Marrero, J.; Gómez, D.; Smichowski, P.; Microchem. J. 2011, 97, 62.

46. Sanchez-Rodas, D.; Alsioufi, L.; Sanchez de la Campa, A. M.; Gonzalez-Castanedo, Y.; J. Hazard. Mater. 2017, 324, 213.

47. Hu, X.; He, M.; Li, S.; J. Environ. Sci. (China) 2015, $29,11$.

48. Cooper, R. G.; Harrison, A. P.; Indian J. Occup. Environ. Med. 2009, 13, 3 .
Submitted: May 23, 2018

Published onlline: September 4, 2018 